\title{
XIV. Notice of a Portrait of John, King of France. By the Right Hon. CHaRLes Tennyson D'Eyncourt, F.R.S., F S.A. In a letter to J. Y. Akerman, Esq., Secretary.
}

Read 18th March, 1858.

\section{MY DEAR SIR,}

THE portrait of John, King of France, which is now placed in the Musée des Souverains at Paris, being, I believe, the only picture honoured by such a distinction, has an especial claim to our notice. Not only is it one of the earliest examples of portrait-painting which has been preserved to us, but the history of the monarch whom it represents is so closely interwoven with that of our own country, as to render him a subject of interest to English archæologists.

Taken prisoner at the battle of Poictiers in 1356, where he saw his army annihilated, and his principal adherents either slain fighting for him or captives with him, John passed a considerable portion of the remainder of his life in England, and died here in 1364. I need not, however, recall to your recollection the events of his captivity, as they formed the subject of a very interesting communication from the Rev. Edward Trollope, F.S.A., which was read to our Society the 29th of January, 1857, and will appear in the Proceedings of the Lincolnshire Architectural Society. ${ }^{2}$ That communication related chiefly to the monarch's residence at the Castle of Somerton, in Lincolnshire; a period of his life peculiarly interesting to myself, as he was conducted to that fortress by my ancestor, William Lord d'Eyncourt, and remained there in his custody. The accounts detailing the King's expenses during his imprisonment at Somerton, from the 11th of August, 1359, to the 21st of March, 1360, enable us to form some idea of his comforts and discomforts, and of the occupations and amusements with which he endeavoured to alleviate the weariness of his captivity. ${ }^{b}$

a Memoirs of the Associated Architectural Societies.

b These accounts form a portion of "Comptes de l'Argenterie des Rois de France au 14" Siècle, publiés pour la Societé de l'Histoire de France, par L. Douet d'Arcq." Paris, 1851, p 193. The accounts of King John extend from 30th June, 1359, to the 8th July, 1360, when the King reached Calais on his return to France. The original MS. is preserved in the Bibliothèque at Paris. The Duc d'Aumale has since discovered among the Condé MSS. the accounts for a previous portion of the King's captivity, from 25th Dec. 1358, to the 1st of July, 1359; which his Royal Highness has printed in the Miscellanies of the Philo- 
When last I visited the Musée des Souverains I became anxious to obtain a faithful copy of the portrait above mentioned; and, by permission of the authorities, the facsimile which $I$ have the pleasure of placing in your hands for exhibition to the Society is the result. ${ }^{a}$ It has been executed for me by $\mathbf{M r}$ Edward Poynter, the son of Mr. Ambrose Poynter the well-known architect. He has imitated with remarkable fidelity the original, including the injuries and blemishes occasioned by time.

The first account that we have of this portrait is furnished by Montfaucon, who, in his "Tresor des Antiquités de la Couronne de France," tom. ii. pl. lv. fig. 1, gives a slight outline of the face, which he describes as "Buste du Roi Jean tiré d'un tableau de M. Gagnieres ${ }^{b}$ peint dans le tems même." The picture seems to have passed from M. Gagnieres' hands into the Bibliothèque at Paris. In the "Notice des Estampes exposées à la Bibliothèque du Roi, 1823," No. 205, a description of it is given, which, after alluding to the propriety of this portrait of King John, "fait de son temps," being placed in a library which had its origin in his reign, goes on to say, "Cette peinture est une espèce de gouache, ou de peinture à la colle; on a pretendu devoir attribuer ce tableau à Jean de Bruges, qui était peintre du Roi Charles V. dit le Sage. La bordure a été faite, à ce qu'on croit, du temps de Louis XII. Elle a été détériorée en 1793."

In 1821 Dr. Dibdin saw the portrait in the Cabinet des Estampes, and describes it as follows : " Hanging up on a pillar at the hither end of the second room you observe a large old drawing of a head or portrait, in a glazed frame, which strikes you in every respect as a great curiosity. M. du Chesne, the obliging and able director of this department of the collection, attended me on my first visit. He saw me looking at this head with great eagerness; 'Enfin, voila quelque chose qui merite bien votre attention,' observed he. It was, in fact, the portrait of 'their good but unfortunate King John'-as my guide designated him." Dibdin was so much pleased with this interesting relic that he employed M. Coeuré, "a young artist of established merit," to make him a drawing of it; which was afterwards engraved, and published as an illustration of his "Tour in France."

biblon Society, vol. ii., 1855-6. The accounts appear to have been kept by Denys de Collors, the king's chaplain and secretary.

a [The facsimile alluded to above is of the size of the original (22 in. by $14 \mathrm{in.}$ ), and executed in water colours. The accompanying illustration (Pl. VIII.) has been reduced from it, and is presented to the Society by the liberality of the author of this communication.-ED.]

b M. Gagnieres formed the valuable collection of drawings of royal and other tombs formerly existing in the French cathedrals and abbeys, which is now in the Bodleian Library, Oxford.

c Bibliographical and Picturesque Tour in France and Germany, 1821, vol. ii. p. 140. 
Yol, xxxviii. Pl, viii, p. 197.

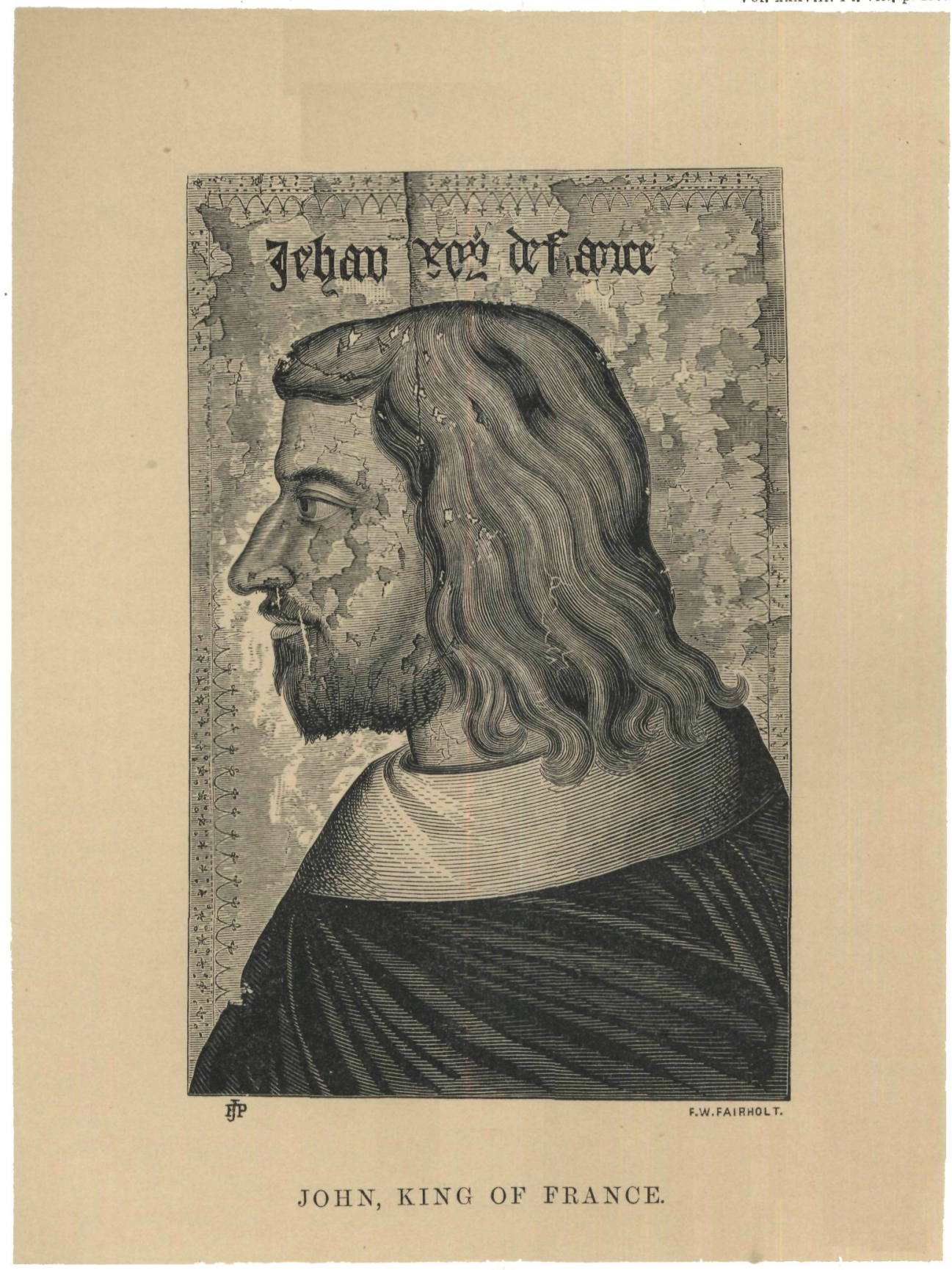

Reduced from a facsimile of the portrait in the Louvre,

made for the Right Hon. C. T. d'Eyncourt. 
He proceeds to say that the original is injured by pieces of the colour having given way in the cheek and about the eye, although not so represented in his drawing; that the painting is executed in a sort of thick body colour upon fine linen, the background of gold worn thin and almost entirely perished; and that there is a sort of frame stamped or pricked out upon the surface of the gold, as seen in illuminations of books of that period. He adds, "It would seem as if the first layer upon which the gold is placed had been composed of the white of an egg, or some such glutinous substance."

Mr. Edward Poynter says :- "The portrait appears to be painted in tempera, or body colour, on a gesso ground, spread upon rather coarse canvas. There is round the portrait a wooden frame, formed of a small ogee moulding, which has been gilded as well as the background. It has evidently been the original moulding round the panel, which was probably let into a wall."

The original picture was removed to the Louvre on the formation of the new Musée des Souverains, in which are collected so many interesting memorials of the various dynasties which have governed France.

I have mentioned that the execution of the portrait has been attributed to Jean de Bruges, painter to Charles V., King of France; but Mr. Edward Trollope has suggested, with much greater probability, that it was the work of Maitre Girard d'Orleans, King John's painter, who was with him in England, and is mentioned in several items of the accounts. This person appears to have discharged a multiplicity of duties; at Easter, 1352, we find him making chairs and other necessary pieces of furniture for the King.

Pour une aune de veluyau asuré des fors, bailliées à mestre Girart d'Orliens, paintre, pour faire les siéges de deux chaières pour le Roy livrées en la dicte chambre au terme de Pasques, 8 escus.

Ledit maistre Girart pour le fust et façon des dictes chaières ouvrées à orbevoies a à deux endrois, paintes et couvertes de cuir par dessouz ledit veluyau $10^{1}$. p.

Ledit maistre Girart pour 2 selles necessaires feutrées et couvertes de cuir et de drap delivrées en la dicte chambre $6^{1} \cdot$ p. $^{\mathrm{b}}$

A similar charge occurs for chairs etc., for six other members of the royal family of France, which seem to have been ornamented with the armorial bearings of the persons for whom they were destined. ${ }^{c}$

a Orbevoies, pierced work filled up at the back,-blind paneling.

b Compte d' Etienne de la Fontaine in Comptes de l'Argenterie des Rois de France au $14^{\mathrm{e}}$ siecle, p. 111. The furnishing of such things seems to have been a privilege of the court painter both in France and Burgundy. See Count Laborde's Notice des Emaux du Louvre. Glossaire, Selle necessaire.

' Comptes de l'Argenterie, p. 117. 
In the same year the marriage of Blanche de Bourbon with Peter the Cruel, king of Castile, furnished further occupation for the King's painter. In the accounts of the expenses we find the following entries under the head of communes choses : $:^{\mathrm{a}-}$

Pour une aune de velluau vermeil des fors, bailliée à maistre Girart d'Orliens, paintre, pour couvrir 2 chaaires, l'une à dossier pour atourner ladicte dame, l'autre sans dossier pour soy laver, 6 escuz et demi.

Ledit maistre Girart pour la façon des dictes 2 chaires les quelles furent paintes d'azur et les testes estancellées de fin or, $14^{1}$. Pour une damoiselle à attourner ${ }^{\mathrm{b}}, 60^{\mathrm{s}}$ par. Et pour une neccessaire couverte de cuir et envelopée de drap, $4^{1}$.

The expenses during the King's captivity show that Maitre Girard was employed in making or repairing the King's furniture, trunks, \&c. ' though the items are not of so sumptuous a character as those mentioned above. He was also commissioned by the King to supply some deficiencies in his set of chessmen, namely five pawns and a bishop. ${ }^{d}$ He seems to have had the charge of some wooden carvings belonging to the King, as another entry notices the purchase of two baskets "pour mettre certains ymages de fust pour le Roy." e The only entries, relating to what we should consider the proper functions of his office, are thus given in the accounts published by his Royal Highness the Duc d'Aumale. In February, 1359, we find ${ }^{\mathrm{f}}:-$

Maistre Girart d'Orliens, paintre et varlet de chambre du Roy, pour plusieurs otilz achetez du commandement du Roy, pour faire certains tableaux que le Roy le a commandé à faire pour li, paié du commandement du dit Seigneur, pour tout xxxiijs. iiijd.

On the 4th of April following is another entry:

Maistre Girart d'Orliens, pour certains hotilx à faire son mestier en certains tableaux que le Roy fait faire, paié du commandement du Roy, ijs. iiijd.

We do not learn from these entries the nature of the pictures which the King had ordered, nor what was their destination. It is not impossible that the portrait which forms the subject of this communication may have been painted by Maitre Girard for the King, to be given, perhaps, to one of his noble visitors and relations, such as the Countess of St. Pol or of Warren.

a Comptes de l'Argenterie, p. 300.

b Demoiselle à atourner, a wooden figure to support a mirror, and the dresses of the lady in whose room it was placed. See Count de Laborde's Notice des Emaux du Louvre. Glossaire.

c Philobiblon Miscellany, pp. 95, 97, 100. Comptes de l'Argenterie, p. 264.

a Philobiblon Miscellany, p. 99.

e Philobiblon Miscellany, p. 112.

f Ibid. 107.

g Ibid. p. 118. 
Maître Girard had been, however, connected with works of art on a much larger scale. A curious document, published in the "Bibliotheque de l'Ecole des Chartes," "is so closely connected with our artist, and contains in itself so many points of interest, that I will venture to transcribe it here, especially as it has appeared only in a publication of limited circulation, and is probably little known in this country. It relates to the works in progress at the royal castle of Vaudreuil, in Normandy, according to the directions of the Dauphin, duke of Normandy, eldest son of King John, and afterwards Charles V., and furnishes so interesting a picture of the style of decoration used in a royal abode during the fourteenth century, that I trust no apology is needed on my part for reproducing the document; it is as follows ${ }^{\mathrm{b}}$ :-

Cest l'ordenance de ce que je Girart d'Orliens ai cautié à fere par Jehan Coste ou chastel du Val de Rueil, sur les ouvrages de peincture qui y sont à parfaire, tant en la sale come allieurs, du commandement Mons" le duc de Normandie, l'an de grace mil $\mathrm{cCC}$ cinquante et cinq, le jour de la nostre Dame en Mars.

Premierement pour la sale, assouvir ${ }^{c}$ en la maniere que elle est commenciée ou mieux; c'est assavoir: parfaire l'ystoire de la vie César, et au dessouz en la derreniere liste une liste de bestes et d'images, einsi comme est commencée.

Item la galerie à l'entrée de la sale en laquelle est la chace parfaire, einsi comme est commencée.

Item la grant chapelle fere des ystoires de nostre Dame, de sainte Anne et de la Passion entour l'autel, ce qui en y pourra estre fet

Item pour le dossier ou table dessus l'autel, iij hystoires; cest assavoir : ou milieu la Trinité et en l'un des costez une hystoire de saint Nicolas et en l'autre de saint Loys; et au dessouz des hystoires du tour de la Chapelle, parfaire de la maniere de marbréd einsi comme il est commencié.

Item l'entreclos, qui est au milieu de la chapelle, estanceler et noter de plusieurs couleurs estancellées.

Item l'oratoire qui joint à la chapelle parfaire; c'est assavoir: le couronnement qui est ou pignon avec grant quantité d'angres, e et l'annunciation qui est a l'autre costé. Et en vij archez qui y sont, vij ymages; c'est assavoir: en chascun archet un ymage, et les visages qui sont commenciez parfaire, tant de taille comme de couleurs; et les draps diaprez nuer ${ }^{f}$ et parfere; et une piece de merrien qui est au dessouz des archez armoier de bonne armoierie ou de chose qui le vaille.

Et toutes ces choses dessus devisées scront fetes de fines couleurs à huile, et les champs de fin or enlevé, $^{g}$ et les vestemens de nostre Dame de fin azur, et bien et laialment toutes ces choses vernissiées et assouvies entierement sans aucune deffaute. Et fera le dit Jehan Coste toutes les œuvres

a Tome i. Deuxiéme série, p. 540. Paris, 1844.

b This document formed part of the collection of MSS. of Baron de Joursanvault; in 1844 it was in the possession of M. Salmon.

c Assouffir, to terminate.

e Angels.

d Imitation of marble?

f Nuancer, shade

g Worked in relief, as were many of the gilt details of the paintings formerly in St. Stephen's Chapel, Westminster, which are of the same period and now in the British Museum. 
dessus dictes, et trouvera toutes les choses necessaires à ce, excepté buche à ardoir a et liz pour hosteler ly et ses gens, en la maniere que l'en ly a trouvé ou temps passé. Et pour ce faire doit avoir six cens moutons, ${ }^{b}$ desquiex il aura les deux cens à présent sur le terme de Pasques et deux cens à la sainct Michel prochainement venant, et les autres deux cens au terme de Pasques après ensuivant.

Accordé et commendé par Mons ${ }^{r}$ le duc de Normandie au Val dè Rueil, le Xxve jour de Mars MCCCLV.

What part Girard d'Orleans took in these works does not clearly appear ; it is possible that he may have sketched the designs, and, being obliged to remain with the King, he may have left them to be finished by Jean Coste. Whether they were ever completed is very doubtful, for, the date of the document being according to the old computation, the transaction to which it refers took place in the spring of the historical year 1356, and in less than six months afterwards the disastrous defeat of the French army at Poictiers must have put an end to all royal works, and the money required for the ransom of the King and his adherents must have prevented any expenditure in ornamenting his castles.

There is one passage in this document of considerable interest, as it bears on that much-vexed question, the invention of oil-painting by Van Eyck. This has been already denied on the authority of other documents; but the agreement for Vaudreuil specifies most distinctly that the colours were to be à huile, that is, mixed with oil.

I have already mentioned that the picture of King John is remarkable as an early specimen of a portrait; that is, a painting intended merely to represent a person, as distinguished from the usual pictures of the period in which the portraitures were accessories. Three religious paintings containing figures of the King are recorded by Montfaucone as existing in his time. One of them was an altarpiece in the chapel of S. Hippolyte, at S. Denis; another was in the Sainte Chapelle, and the third in the chapel of S. Michel at Paris; but the stormy period which has intervened, and the violence directed against every reminiscence of royalty, have in all probability led to their destruction.

Believe me to be, my dear Sir, sincerely yours,

Bayons Manor, 15th March, 1858.

C. D'EYNCOURT.

a Fire-wood.

- Mouton, also called florin d'or au mouton. This coin, so named from its having upon it the Agnus Dei, was then worth about $4 s$, sterling.

c Montfaucon, Tresor des Antiquités de la Couronne de France, tome ii. pl. lv.

VOI. XXXVIII. 